\title{
Heritage Interpretation as Tool in Cross-Cultural Communication: Challenges and Solutions in the Work of Guides-Interpreters
}

\author{
Elena A. Weber* \\ Irkutsk State University \\ 3 Karl Marx Str., Irkutsk, 664003, Russia
}

Received 13.02.2018, received in revised form 16.04.2018, accepted 27.04.2018

\begin{abstract}
This article introduces the notion, definitions, principles and some techniques of heritage interpretation. Being a useful tool for overcoming challenging translation, cultural and crosscultural barriers heritage interpretation serves as means of transforming touristic product delivered by language mediators (guides) into a memorable, valuable and powerful product of "experience economy". One of benefits of using techniques of heritage interpretation in guiding is the fact that it helps audiences (tourists, museum and information center visitors) achieve desirable state of selfactualization. Heritage interpretation has grown into profession which offers its effective tools for professional communication. Principles of interpretation are introduced from the perspective of some communicative theories, cognitive theory, communicative psychology.
\end{abstract}

Keywords: Heritage interpretation, communication, cross-cultural barriers in professional communication.

DOI: 10.17516/1997-1370-0299.

Research area: linguistics.

\section{Introduction}

The mission of a guide-interpreter in crosscultural communication in the sphere of tourism is really hard to overestimate. The guides are sometimes the only representatives of native population the tourists contact with and therefore they act as models to judge about national features, stereotypes, smartness, mastery of skills (including the one of foreign languages) and sometimes even typical look. The guides are not only in charge of the organization of the overall program, content of tours, accuracy in translation in the course of museum programs, they bear a responsibility of making the program "worthy", because clients pay for the service and that is why always assess the quality of rendered services. Travel agencies compete with each other so the excellency of service (among other things the guide's work) sometimes helps them win over rivals in business, attract more clients knowing that the word of mouth is one of the best kinds of advertisement.

(C) Siberian Federal University. All rights reserved

* Corresponding author E-mail address: elenaweber.islu@mail.ru 


\section{The role of heritage interpretation}

\section{in tourism as industry of entertainment}

Tourism is often referred to as industry of entertainment (Pine II, Gilmore, 1999; Brochu, Merriman, 2015). Such new and actively developing industry as experience economy suggests that people are not only looking for complete and inspiring experiences, they also know what they are paying for, and the more they travel, the higher are their expectations. The wider is the experience they compare this particular delivered program with, the heavier is the burden for the guide to realize he or she is being constantly compared with other western counterparts.

With services increasingly commoditized, experiences in tourism have emerged as the next step in what is called "the progression of economic value”. One shouldn't refer experience in any sphere of business, including tourism an "amorphous construct"; anything serving as offering including services, goods, commodities are bits of experience. As Pine and Gilmore refer, “in today's service economy, many companies simply wrap experiences around their traditional offerings to sell them better" (Pine, Gilmore, 1999: 12). Understanding the value of commodity and its benefits owners of businesses turned to just offering something "designing engaging experiences" and that commands a fee. Experience-economy pioneer Walt Disney suggested that to be worthy and valuable any services should be "memorable", which means they are assessed individually and could be called such only in case they engage emotionally, physically, intellectually and spiritually. Experiences have higher perceived value, therefore customers are ready to pay more for them (Brochu, Merriman, 2015: 40-43). This is probably what psychologist Abraham Maslow referred to as "peak experience", which could only be reached by means of meeting "basic needs" of customers and moving higher and higher up the pyramid of needs while rendering services, satisfying customer's needs of safety, love and belonging, esteem and finally, selfactualization, helping them achieve desirable state of self-actualization (Maslow, 1954, 1971; Mittelman, 1991; Tay, Diener, 2011; Hollyforde, Whiddett, 2002).

This task may seem even more challenging in the sphere of tourism where cross-cultural differences are not easy to overcome, where service providers are balancing between overcoming economic difficulties and choosing and hiring experienced and gifted linguists to bridge communicative differences. So in this situation travel companies trying to become commoditized businesses lay unbearable tasks upon guides-interpreters who are set to solve too many task - they are supposed to be knowledgeable, organized, witty and charming, quick in finding solutions, polite, they should demonstrate excellent mastery of foreign language that guarantees overcoming crosscultural difficulties and who makes service an experience, preferably positively unforgettable. This task would seem absolutely impossible unless you have a correct tool.

\section{Heritage interpretation as a growing profession in Europe and the USA}

In the USA and many European countries heritage interpretation serves as a tool to help guides-interpreters reach desired efficiency. Heritage interpretation has become a profession not only for thousands of nature guides, city guides, museum guides and docents, rangers in national parks and forests, but it is a field that offers dozens "how-to-do" methods for developing outstanding travelers' experiences, personal and non-personal interpretative products, and is a real engine that allows to bring tourism sphere to new, more qualitative level. 
Heritage interpretation is a communicative approach that not only helps entertain travelers, but that allows audiences to learn more effectively about hard-to-render cultural phenomenon or traditions, to lead people to understanding, love and care about resource they are getting acquainted with be it a natural, cultural or historical sight, museum piece, local legend, tradition or artifact. Interpretation "reveals the meaning and relationships through the use of original objects, by firsthand experience, and by illustrative media, rather than simply to communicate factual information" (Tilden, 2007). According to National Association for Interpretation, interpretation is a "mission-based communication process that forges emotional and intellectual connections between the interests of the audience and meanings inherent in the resource" (Definitions project http://www. definitionsproject.com/definitions/index.cfm). It is a cross-discipline field uniting communicative theory and psychology, sociology, economics with other related sciences.

The key figure in this communicative process is an interpreter. It is not the guideinterpreter who is able to reveal meaning or establish relationships for visitors learning about something. Rather the role of this professional is to organize the process of learning (interpretive encounter that can be both personal and nonpersonal (self-guided) (Ham, 2013: 4) in such a way that the visitor himself finds place of a new concept in the sphere of his concepts. An interpreter stimulates thinking process, the process of discovery of meanings in minds of visitors, it is a provocation to think and establish connections with a place, a thing, a concept to personal and individual experience of a visitor. Only in this case a finished interpretive program or device is called interpretive product, which is characterized by real commercial value.

Interpretation can be delivered through any communication medium and be used not only by guides but by anyone who provides communication with "pleasure seeking audiences" in national parks, museums, forests, wildlife refuges, zoos and other places where visitors are involved in process of learning something new. Being technique for "explanation of the natural, cultural or historic values attached to places" (Interpretation Handbook and Standard, 2005: VIII) it enables visitors to gain insight and understanding about the reasons for conservation and ongoing protection of our heritage and is considered to be a profession in many European countries and in the USA because it involves public service with social responsibility, research-based approach, it rests on specialized education, training and programs of acceleration and certification, it has established codes of ethics and provides life-long learning. Interpretive services are available in federal agencies (such as USDA Forest Service, US National Park Service, US Bureau of Land Management, the National Aeronautics and Space Administration, US environmental Protection Agency), there are official positions of interpretive designers, interpretive guides, interpretive rangers in local, county and municipal agencies, in nonprofit and non-governmental organizations (Knudson, Douglas, 2003).

Interpretation passed through evolution to become a full-fledged philosophy of learning that joins theoretical principles of communication theory and psychology with practical guiding tools, pedagogical and andragogical wisdom with inspiration of intuitive learning. It dates back to the late $19^{\text {th }}$ century when some outstanding naturalists, teachers, journalists, scientists, among them Enos Mills, John Miur, William Lewis, Freeman Tilden, made first attempts to observe and describe the art of guiding becoming the pathfinders of new interpretive theory (Mills, 2015; Miur, 1980; Tilden, 2007).

As Freeman Tilden noted "Interpretation is an art, which combines many arts, whether 
the materials presented are scientific, historical or architectural. Any art is in some degree teachable" (Tilden, 2007: 26). Active development and maturing of interpretation as a profession are also manifested by formation of professional communities (among them NAI - National Association for Interpretation ${ }^{1}$, Interpret Europe ${ }^{2}$, etc.), as well as development of training programs, refresher courses for professionals (such as offered by NAI), university courses and master programs, adoption and spreading of official statements (e.g. Freiburg Declaration ${ }^{3}$, issuance of journals for professionals, such as Journal of Interpretation Research, Legacy, etc.

Interpretation joins old traditions of story-telling and new science. Techniques of storytelling and narrative genres are time-proven methods of making events, cultural phenomena, historical sights relevant to audiences. As Lisa Brochu and Tim Merriman note, "those of us who have chosen interpretation as a profession are joining an ancient and honorable tribe that includes shamans, poets, historians, and philosophers" who lived before the term heritage interpretation was ever coined (Brochu, Merriman, 2015: 2). But on the other hand interpretation can be also called a young science because it is only in the period of some 50-60 years most of books on its principle and tools have been written. If formerly the skill of storytelling was considered an art, gift and talent of some individuals, these new scientific works set our real tools and methods how to master the art of interpretation and how to introduce them correctly into work. The mystery and success of storytelling genre could be illustrated by M.Bakhtin's words, who wrote: the author "looks at himself through the eyes of another" due to which he sees his inner world from inside, putting himself in his position and helping him experience himself (Bakhtin, 1990).

\section{Principles of heritage interpretation}

Six principles of interpretation introduced by A. Tilden in the 1950-es for many years have become guidelines for interpretation professinals to follow, essence of wisdom to think over and to implement to practical life. They evolve, get modified, take various forms, are implemented by more modern tolls but still remain basic strategies to take into consideration.

1. Any interpretation that does not somehow relate what is being displayed or described to something within the personality or experience of the visitor will be sterile.

2. Information, as such, is not interpretation. Interpretation is revelation based upon information. But they are entirely different things. However, all interpretation includes information.

3. Interpretation is an art, which combines many arts, whether the materials presented are scientific, historical, or architectural. Any art is in some degree teachable.

4. The chief aim of interpretation is not instruction, but provocation.

5. Interpretation should aim to present a whole rather than a part, and must address itself to the whole man rather than any phase.

6. Interpretation addressed to children (up to the age of 12) should not be a dilution of the presentation to adults, but should follow a fundamentally different approach. To be at its best it will require a separate program (Tilden, 2007).

We will try to introduce the first three principles of interpretation in detail, trying to describe them from linguistic perspective.

Experience economy experts offer their guidelines how to turn communicative product into a real experience product. One of characteristics of real experience product is customer's participation which means that guides should try to provide dialogical rather 
than monological form of presentation of tours, active participation of visitors, tourists in the programs, which is achieved through customers playing key roles in creating the performance or event that yields the experience. This is probably what F. Tilden meant when he wrote that any interpretation must be relevant to a visitor (principle 1).

In terms of cognitive map theory, people process information in relation with already existing information. Simplified informational units and paths of commonality form cognitive maps, that are considered to be structures of storage and organization of information. From this perspective, interpretation acts as external stimuli that activate previously formed maps, allowing the audience to perceive and store the information in accordance with what they already know and remember. The art of interpreter in this case is to guess (based of the knowledge of the audience) what common knowledge may be relevant and serve as a trigger to deepen the existing knowledge. As soon as cognitive map is triggered it is actually easier to learn more and with higher interest (Hammitt, 2014; Beck, Cable, 2011).

As Richard Saul Wurman, an American architect and graphic designer and the founder of TED wrote, "Learning can be seen as acquisition of information, but before it can take place, there must be interest; interest permeates all endeavors and precedes learning...Learning can be defined as the process of remembering what you are interested in" (Wurman, 1989: 23).

One of the practical examples of such an approach is specially designed historical concert programs in Irkutsk museum of Decembristsrevolutionaries during which along with musical compositions characterizing this historical epoch tourists are invited to read out loud some translations of Russian poetry, for example, by Alexander Pushkin, (out loud), in front of the group members:
Deep in Siberia's mines, let naught

Subdue your proud and patient spirit.

Your crushing toil and lofty thought

Shall not be wasted - do not fear it. $<\ldots>^{4}$.

Singing a Russian romance of the $19^{\text {th }}$ century composed by Peter Tchaikovsky and Alexey Tolstoy together with professional performers but in their own native language, understanding the text due to interlinear translation could make such a program unforgettable:

Средь шумного бала, случайно,
[sret' shúm-na-va bá-la, slu-chá j-na]
In the midst of the noisy ball,
В тревоге мирской суеты,
[ftre-vó-ge mir-skój su-e-tý]
amid the anxious bustle of life,
Tебя я увидел, но тайна
[ti-bjá ja u-ví-dil, no táj-na]
I saw you, but a mystery
Tвои покрывала черты.
[tva-ee pak-ry-vá-la cher-tý]
Obstructed your features.

Popular "shaman-tours" to one of Siberian villages which help foreign visitors learn more about traditions, religion and cuisine include some simple but enjoyable role games in which visitors perform in the roles of the elderly of the tribe, a young married couple, parents, etc.

One more dimension of this strategy is connection of a visitor to a resource he or she learns about. There is a wide spectrum of techniques that may help visitors reach absorption, or immersion. Along with non-verbal tools such as historical stylizations, sights, sounds, and smells, graphic communication and infographics there are verbal ones, for example, self-referencing and labeling (Ham, 2013: 39-40).

The first one is a technique that allows the audience to think about themselves and their 
experience in terms of particular communicative situation. Phrases like "Have you ever heard of...?", "Remember the last time you...?", "Did anyone of you try to..?" help easily the audience put themselves easily in the situation described by the guide. The use of personal pronouns "you", "I", "we" and possessive pronouns "your", "my", "our" which are considered to be powerful words, help communication appeal to things the audiences care about, their values, beliefs, lives, personal spaces. The more personal the communicative appeal is, the more relevant it is.

Labelling is a method of classifying people in positive, neutral or negative ways. In communicative situations it helps listeners associate themselves with certain class or group and due to this the information shared with them becomes more relevant. Example of labels are: "People who live in cold climate...", "If you are a person who have been to Russian banya...", "The worst enemies nowadays are those numerous lovers of sable fur...".

The second principle introduced by F. Tilden emphasizes the necessity to reveal deeper meaning rather than to provide factual or cognitive information. It is self-evident that any interpretation is based on information. Nevertheless Ted and Cable call information the "raw material" of interpretation (Beck, Cable, 2011), but the facts the guide refers to should be first of all selected to provide revelation. Because guides read a great deal of written scientific sources it is often a problem for them to get rid of habit to stop acting as "walking encyclopedia" and to provide revelation by carefully selected information instead.

The key technic interpretation offering to reach this rather challenging objective is to connect tangible and intangible dimensions of the described concept, realia, artifact etc. Tangible characteristics of an object are those which are concrete, can be touched, seen, felt. They are usually the features that are observed by visitor, but the choice of features to comment on is a significant choice by interpreter because it means further explanation of what lies behind them, that may guarantee discovery of some hidden, previously unknown characteristics. There is no sense to comment on as many as possible features of a thing, event, etc. Intangible dimensions cannot be perceived by senses, they are broader meanings related to values, processes, ideas, feelings. To reach success in cross-cultural communication, to make a program a real memorable experience an interpreter should try to introduce universal concepts (which are intangible by nature) into a story, description of event, talk on something which is foreign to audience's culture. Many of such universal concepts include opposites (death life, happiness - sorrows, love - hatred, elation despair, etc.). For example, the story about the life of Decembrists-revolutionaries in Siberian exile would be perceived more dramatically if it is presented from the perspective of hardships they lived through, love that helped them support each other, hope to return home, to the European part of Russia one day, patriotism that made them take part in coup-d'etat, etc. Presented in such a way this story would be touchy, more memorable, because it would echo in their hearts, help find similarities from their personal experience or the experience of other people they know better.

It is important not only to mention the notions or concepts but to connect them in such a way that tangible characteristics become associated with more meaningful, intangible features hidden behind them. This is how powerful stories are born out of whole cloth. The real power of a resource in this case is not in its authenticity or price, but in its capacity to reveal meanings, make audience think, form associations or intellectual connections between the interests of visitors and the resource they are visiting. As Geert Hofstede wrote about culture manifestations: "Symbols, 
heroes, and rituals have been subsumed under the term practices. As such they are visible to an outside observer; their cultural meaning however is invisible and lies precisely and only in the way these practices are interpreted by insiders" (Hofstede, 2010: 8-9).

The third principle carefully though over by modern interpretive scholars was named "the gift of story" (Beck, Cable, 2011: 21) because in many things an interpreter is an actor, success of events depending of his or her artistic skills of presenter. The genre of storytelling is as old as human history and despite the very optimistic statement of F. Tilden that it is teachable to certain degree, it remains a rather mysterious art. To make oral story effective, to add interest the interpreter may employ various strategies, e.g. enrich it by anecdote, dramatic performance, myth, puppetry, visual arts, legend, tale, reading a poem, singing a song even dancing.

The well thought-over use of analogies, similes, metaphors, repetitions to create memorable messages also may make a story a piece of art. Analogies allow one to present new and hard to perceive information in a more understandable way. So, the statistics or scientific data presented in a relevant for particular foreign audience manner, due to the use of analogies may significantly facilitate the learning process and make it more enjoyable: e.g. instead of presenting the volume of water in lake Baikal in square kilometers -23000 , it is better to say that it equals the annual outflow of all the world's rivers, or that when shared with every human being of the world in amount for sufficient daily consumption it would be enough for 40 years, or that the lake's volume is more than the one of all Great Lakes combined, or it is $23 \%$ of all drinking water of the planet, etc.

Many institutions using interpretation in their work desire to help their visitors begin to value the place, preserve the area, take part in conservation efforts of parks, forests, wildlife refuges, battlefields and other monuments of culture, that is to reach some resource-friendly behaviors, such as stewardship, donations, volunteering, etc. So, interpretation attempts to influence behavior and attitude of people towards some resource therefore any act of interpretation is a perlocutionary act. From this perspective interpretation can be viewed as verbal or non-verbal manipulation. According to P. Parshin, verbal manipulation is "an influence upon individual and/or collective consciousness and behavior provided by various verbal means" (Parshin, 2010). Language acts as a tool of coordination of human activity in certain sphere, and there are certain psychological, cognitive, logical, sociological, communicative-semiotic and other prerequisites for such manipulation.

Desired response to manipulation can be fear-motivated or aspiration-motivated. The first kind of motivation is considered to be shortterm, while the second one may generate longterm change. Both forms of manipulation arise out of temporary dissonance in the system of knowledge caused by newly introduced elements of information. Because human conscience tends to remain stable and resists cognitive dissonance it may reach consonance due to change of value, behavior of individual (Festinger, 1957; Cialdini, 2001).

Such an influence upon behavior through interpretation is possible due to various linguistic tools, first of all by means of emotionally charged words, figures of speech, phono-semantic tools in oral presentation and metagraphemic tools in written ones, a choice of syntactic structures, cognitive operations such as metaphors, examples, analogies, etc.

Being effective linguistic manipulative tool any interpretation is aimed at "making some difference on purpose" (Ham, 2013). Success in such approach is achieved when the audience 
is made to think about some issue, put it in personal perspective, be it a historic event and its consequences, ecological problem or the role of some plant in human's life.

Depending on how the interpreter builds the program he or she might expect or plan a certain effect of it upon the audience. Development of a certain theme within the program results in thoughts and speculations of the audience about it. Following interpretive approach, using available tools professional guides may hope that their planned effect coincides with the real one, so the theme they developed echoes in the thought about the same theme or close to it, within the so-called zone of tolerance, "a subjective area within which an interpreter judges the thoughts provoked by an interpretive product to be acceptable. Thoughts that fall within a communicator's zone of tolerance are considered to be supportive or consistent in some way with the theme the communicator was trying to develop" (Ham, 2013: 257, 149-171).

One should differentiate several zones of tolerance. In case it is important just to make people think about the subject matter, provoke them to form their personal opinion about something or capture a sense of diversity in opinions when, for example, presenting the unknown possibilities of science or social issues behind some event, a/the guide may not expect the audience to take any exact point of view, so interpretation falls into an unrestricted zone of tolerance. Very often myths, fairy tales, legends may render many messages or open ending which can be perceived in different ways.

With a wide zone of tolerance guides expect the audience to take away almost any personal meaning but consistent with the intended theme of product. People may come to some conclusions, reevaluate many things at the same time, still some organizations using interpretation in their work to produce desirable effect would prefer the audience to have their thoughts, conclusions, speculations to be connected with resource, to guarantee positive memories about the site, future repeated attendance of the place.

The narrow zone of tolerance is often shaped by the mission of an institution, in some situations the interpreter may like the audience to have little variation of the theme introduced, to get the right message. The Narrow zone is also preferable when it is necessary to influence audience behavior in certain situation. For example, when a program with children aims at their understanding why littering is harmful practice in nature, there cannot be alternative options but the only one, meant by the interpreter.

Sometime analysis of feedback is available when travel agencies (other institutions working with audiences) ask tourists (audience) to express their opinions about the service. In case interpreters have access to such data they can learn whether they have reached desired reaction of their audience, whether their response falls within a certain zone of tolerance.

\section{Conclusion}

Principles of heritage interpretation introduced in tourism communication can help guides become better professionals, present them new pathways for self-improvement and motivation, open new learning opportunities to visitors, upgrade the quality of tourist product, make process of sharing information about local heritage sites real pleasure.

\footnotetext{
http://www.interpnet.com

http://www.interpret-europe.net

See full text at: http://www.interpret-europe.net/fileadmin/Documents/publications/Fbg-declaration-web.pdf

Translation by I.Zheleznova http://www.poetarium.info/pushkin/siberia.htm

Translation by Anastasia Witts www.singrussian.co.uk/wp-content/uploads/2014/09/Tchaikovsky-At-the-ball.pdf
} 


\section{References}

Bakhtin, M.M. (1990). Art and Answerability University of Texas Press Slavic Series Early Philosophical Essays.

Beck, L., Cable T. (2011). The Gifts of Interpretation, Sagamore Publishing LTD, Urbana IL.

Brochu, L., Merriman T. (2015). Personal Interpretation, InterpPress, Fort Collins, CO.

Cialdini, R. (2001). Influence: Science and Practice. Allyn \& Bacon, 2001.

Festinger, L. (1957). A theory of cognitive dissonance, Evanston, IL, Row \& Peterson.

Ham, S.H. (2013). Interpretation - Making a Difference on Purpose, Fulcrum Publishing, Golden.

Hammit, W. (2014). A theoretical foundation for Tilden's interpretive principles. In Journal of Environmental Education, 12 (3): 13-16. Available at: http://www.tandfonline.com/doi/pdf/10.1080/00 958964.1981.10801905?needAccess $=$ true (accessed 20 December 2017)

Hofstede, G. (2010). Cultures and Organizations: Software of the Mind McGraw-Hill Education.

Interpretation Handbook and Standard. Distilling the Essence (2005). (ed. by Fiona Colquhoun), Department of Conservation, Wellington.

Knudson, D, Cable, T, Beck, L. (2003). Interpretation of cultural and Natural Resources. State Park, PA: Venture Publishing, Inc.

Maslow, A.H. (1954). Motivation and Personality. Harpaer \& Row.

Maslow, A.H. (1971). The Farther Reaches of Human Nature, Penguin Books.

Mills, E. (2015). Adventures of a Nature Guide. Temporal Mechanical Press.

Mittelman, W. (1991). Maslow's study of self-actualization: A reinterpretation. Journal of Humanistic Psychology.

Muir, J. (1980). To Yosemite and Beyond. Madison: University of Wisconsin Press.

Parshin, P. (2010). Verbal manipulation. Available at: http://www.krugosvet.ru/enc/gumanitarnye_ nauki/lingvistika/RECHEVOE_VOZDESTVIE.html

Pine II, B.J., Gilmore, J. (1999). The Experience Economy: Work is Theater and Every Business a Stage. Harvard, MA: Harvard Business Press.

Tay, L., Diener, E. (2011). Needs and subjective well-being around the world. In Journal of Personality and Social Psychology.

Tilden, F. (2007). Interpreting Our Heritage, The University of Northern Carolina Press, Chapel Hill.

Wurman, R.S. (1989). Information anxiety. New York: Random House. 


\title{
Интерпретация наследия как инструмент \\ межкультурной коммуникации: \\ трудности и решения в работе гида-переводчика
}

\author{
Е.А.Вебер \\ Иркутский государственный университет \\ Россия, 664003, Иркутск, ул. Карла Маркса, 3
}

В статье представлено понятие «интерпретация наследия», его определения, принципь и техники. Будучи удобным инструментом для преодоления переводческих, культурных и межкультурных барьеров, интерпретация наследия служит преобразованию туристического продукта, представляемого языковыми посредниками-гидами, в запоминающийся и иенный продукт «экономики впечатлений». Одним из преимуществ применения техник интерпретации наследия в работе гида является то, что такой подход помогает аудитории (туристам, посетителям музеев и визит-иентров) достигать желаемого состояния самоактуализации. В Европе и США интерпретация наследия развивается как самостоятельное профессиональное направление, предлагающее свои эффективные инструменты для профессионального общения. В данной статье предпринимается попьтка рассмотрения принципов интерпретации наследия с позиции положений некоторых теорий коммуникации, когнитивистики, коммуникативной психологии.

Ключевые слова: интерпретация наследия, коммуникация, межкультурные барьеры в профессиональной коммуникации.

Научная специильность: 10.02.00-лингвистика. 